【方法】新旧CM-H[コニカ(株)]のカブリ, 相対感度, 平均階調度は 距離法により求めた特性曲線より，抢よび粒状度はRMS粒状度で, 鮮鋭度は矩形波MTFで相対的に比較する。

【結果および考察】1. カブリは変わらなかった，2，感度は変わらな かった. 3. 平均階調度は高くなっていた. 特に, 高濃度部の平均 階調度が高かった．4．粒状度はごくわずかに劣っていた．5．鮮鋭 度はごくわずかに優れていた。

以上の結果より，吸収差の小さい組織を含む乳房の撮影には嵪コ ントラストシステムの感材系が必要とされているので, 新しく発売 されるフィルムは現在発売されているフィルムに比べて乳房撮影に は有利であると思われる。

\section{8 乳房撮影用両面乳剂フィルムの特性}

徳島大学医療技術短期大学部 島崎佳世，北村怜子，猿渡理惠

球磨郡公立多良木病院・放射線部 西村 綾

国立療養所東徳島病院・放射線科 安友基勝

徳島大学医療技術短期大学部 井村裕吉, 八木浩史

【目的】乳房撮影用両面乳剂(片面増感紙)フイルムの特性を評価す 万。

【方法】MIN-R 2000(片面乳剂) とMIN-R L (両面乳剂) (ともにKodak) のカブリ，相対感度，平均階調度は距離法より求めた特性曲線よ り, 㧍よび粒状度はRMS粒状度抢よびWSで, 鮮鋭度は矩形波MTF で相対的に，MIN-R 2000を基準に比較する。

【結果および考察】1。カブリはほとんど変わらなかった，2．相対感 度は少し低かった．3．平均階調度はほとんど変わらなかった４４． 低濃度部のコントラストは少し高かった，5，高源度部のコントラ ストは少し低かった。 6 ，バック(増感紙と密着しない)乳剤の影響 は，濃度が約 2.5 以上で現れた。7. 粒状度は少し優れていた，MINR Lのみでは低濃度部の粒状度が高濃度部のそれより劣っていた。

8. 鮮鋭度は少し劣っていた，MIN-RLのみでは低濃度部の鮮鋭度が 高濃度部のそれより優れていた。

以上の結果より，MIN-RLの発売目的であるスキンラインの描出 は優れていると考えられるが，クロスオーバ効果の影響でバック乳 剂が影響する高濃度部では鮮鋭度が劣化する。

$179 \mathrm{NEQ}, \mathrm{DQE} に よ る$ 新しい增感紙フィルムシステムの総合評 価

\section{藤田保健衛生大学衛生学部 藤井茂久，浅田恭生}

【目的】増感紙フィルムのシステム特性は，臨床における病変の検出 や診断能に大きな影響を与えることが知られており，病変(信号)を 検出する能力の高いシステムのほうが優れたシステムである。今 回，新しく開発された増感紙フィルムADシステムは，従来の高感 度，高鮮鋭度を維持しつつ，粒状性の问上を図った感材システムで ある，この增感紙フィルムシステムの評価としてNEQ $(\mathrm{u})$ とDE $(\mathrm{u})$ でシステムの信号検出能力と量子検出効率を評洒し検討した。

【方法】使用増感紙フィルムシステムは, HG-Mk/newUR-2, HG-Mk/ newUR-3, HG-M/UR-2, HR-3/HR-Sの 4 種類を用いた。これらの感 材システムで，特性曲線，MTFおよびウィナースペクトルを測定し た。測定値から $\mathrm{NEQ}(\mathrm{u})$ とDQE $(\mathrm{u})$ を計算にて求めた。

【結果】SHRシステムでの $\mathrm{NEQ}(\mathrm{u})$ と $\mathrm{DQE}(\mathrm{u})$ は相反関係を示し， $\mathrm{AD}$ システムでの $\mathrm{NEQ}(\mathrm{u})$ とDQE(u) は比例関係を示した。また，新しい $\mathrm{AD}$ ステムと従来 $\mathrm{AD}$ ステムでは新しいADシステムの方が従来の

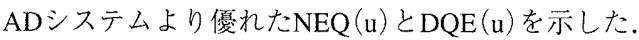

【まとめ】新 $\mathrm{AD}$ システムは, SHRシステムや従来ADシステムに比 ベ，少ないX線量子数でのX線利用率が高いことから，感度を維持 し，画質向上を図った増感紙フィルムシステムであると考えられ た.
180 ウエット式とドライ式レーザーイメージャにおけるCR画像 の粒状性評価

藤田保健衛生大学衛生学部 中村康隆，朝倉裕子，松岡慶子

藤井茂久，浅田恭生/藤田保健衛生大学病院·放射線部 佐藤鼻爾 小林謙一，赤堀竜一

【目的】当院では，同一メーカのウエット式とドライ式のレーザーイ メージャをCRに接続し使用している，今回，ウエット式とドライ式 レーザーイメージャの性能評価をするために，CRにおけるウィナー スペクトル (WS)を測定して，而現像方式による粒状性を評価検討し た。

【方法】レーザーイメージャの性能評湖として，オーバオールWSを 測定して粒状性を評洒した。使用レーザーイメージャはウエット式 (FM-IM D) とドライ式(FM-DP L)の各 1 台を使用した。性能評価項 目として，L值の変化によるWS値，線量変化によるWS值を測定し た。

【結果】CR画像において，ウエット式とドライ式の両方式共に，L値 の変化では，L值が大きいほど粒状性は向.上， 線睹の変化では， 低線量ほど粒状性が低下した。また，ウエット式とドライ式の闻者 間にはWS值の差が認められなかった。

【まとめ】現像処理スピードの低下を除けば，ウエット式と同程度の 画質で，かつランニングコストの大㜚な軽減が可能であるので，ド ライ式レーザーイメージャの有用性は高いと考えられた。

181 ファイバチャネルおよびWEB技術を用いたPACSの構築 北里研究所メディカルセンタ一病院 柳田 智，上野 勉，洲崎義弘 コダックメディカルインフォメーションシステム＼cjkstart脇神浩二

【目的】從来放射線画像ネットワークは，DICOM通信プロトコルを用 いた方法が広く取り入れられて抢り標準化されている。当院では, 平成12年12月から放射線科画像ネットワークの一部にファイバチャ ネルネットワークを利用し，院内への画像配信ではHIS端末を利用 してWEB技術を用いたトータル画像ネットワークシステムを構築し 良好な運用結果が得られている。われわれは，各ネットワークの ビュアの画像表示時間を測定し，今回構築したネットワークを検証 したので報告する。

【方法】1。サーバに蓄積された胸部CT画像100スライス分のデータが 表示できる時間を，各ネットワークのビュアで測定する．2．ファ イバチャネルネットワークに接続されたビュアから同時にサーバに アクセスし，胸部CT画像100スライス分のデータが表示できる時間 を測定する。

【結果】1．院内配信WEBビュアは，放射線科ネットワーク内のWEB ビュアに比べ画像表示に時間を費やした．2．ファイバチャネルに 接続されたビュアでは，同時接続しても単独で接続した場合と表示 時間は変わらなかった。

【結論】モダリティーサーバ間はDICOM通信プロトコルである必要性 があるが，サーバービュア間ではそれぞれの施設にあった通信プロ トコルや配信方法を使うことによって施設にあった画像ネットワー クが構築可能であると考える. 今回，ファイバチャネルネットワー クを用いることで迅速な診断を行うに有用な環境を構築することが できた．また，院内への画像配信は既存のHIS端末でWEBプロトコ ルを用いることにより安価に構築することができたが，表示時間や 通信速度を考慮すると今後インフラの整供が必琶と考える。

182 PACS化に伴う放射線部門業務の改善(第 1 報) 一放射線部門 業務効率の改善 -

NTT東日本関東病院・放射線部 今井宜雄，芳澤康徳，福地達夫 濱野浩二，塚本篤子，奥秋知幸，伊藤照生，若松 修

【目的】当院では平成12年12月から全病院的掣子化システム運用を開 始するに伴い，放射線システムもフィルムレスを含めたPACSシス 